\title{
RESEARCH ON PERFORMANCE MEASUREMENT AND SIMULATION OF CIVIL AIR DEFENSE PPP PROJECTS USING SYSTEM DYNAMICS
}

\author{
Lingyi TANG, Yibo YUE, Xiaer XIAHOU, Shi TANG, Qiming LI* \\ Department of Construction and Real Estate, School of Civil Engineering, \\ Southeast University, No. 2, Southeast University Road, 211189 Nanjing, China
}

Received 4 February 2021; accepted 21 April 2021

\begin{abstract}
Public Private Partnership (PPP) mode is increasingly applied in civil air defense (CAD) projects to improve project quality and reduce the government's financial pressure. Because CAD project has different attributes during wartime and peacetime states, it's necessary to comprehensively consider the project performance under different states to conduct scientific performance measurement. This paper focuses on the process of construction, operation, and handover of CAD PPP project to construct a unified project performance measurement indicator system, then a system dynamics (SD) model is established to carry out dynamic performance measurement and simulation of CAD PPP project under different social states respectively. A case study is conducted to verify the effectiveness of the proposed SD model, model validation, sensitivity analysis and result analysis were included as well. The study result can make the project performance management of CAD PPP more scientific and reasonable, and help decision-makers to formulate effective performance improvement strategies. It's found out that government plays an important role in CAD PPP projects, when resources are limited, the government should give priority to measures such as reducing tax rates and increasing subsidies to ensure project benefits. The research methods can also provide reference for performance measurement of other PPP projects.
\end{abstract}

Keywords: CAD project, Public Private Partnerships, indicator system, system dynamics, performance measurement, case study.

\section{Introduction}

CAD project can provide shelter for personnel and materials during wartime to ensure their safety (Rossborough, 1976), while during peacetime it can be used for production and operation. CAD project can improve the country's air defense capabilities and the ability to resist natural disasters, while it's also an important part of urban underground space development and utilization. Therefore, CAD projects have the characteristics of public welfare, and the development and construction of CAD is an important responsibility of the government.

In past years, the investment and construction of CAD projects are mostly relied on direct investment from government (Chester \& Zimmerman, 1987). Restricted by government financial limitations, the construction of CAD projects cannot keep up with the economic and social development peace, and they suffer from issues such as insufficient numbers, unreasonable project distribution, and inadequate project maintenance (Xu, 2014). The application of PPP mode in CAD projects to introduce social capital has advantages in solving government funding difficulties, expanding investment channels, and improving operational efficiency. The framework to illustrate the capital flow and relationships between stakeholders of CAD PPP project is shown in Figure 1.

CAD PPP project has the characteristics of high risk, long duration, complicated procedures and multiple stakeholders (Tang et al., 2010), thus it is necessary to implement effective project measurements to ensure the project success. The purpose of project measurement for CAD PPP projects is to improve the scientific level of project decision-making through dynamic evaluation and feedback mechanisms, promote the rational allocation of resources to achieve the expected goals of all project participants (Yuan et al., 2012). Establish a full life cycle performance measurement mechanism is an important measure to maximize the public benefits of CAD PPP projects (Bassioni et al., 2004). Numerous researchers have proposed various means to measure project performance

*Corresponding author. E-mail: seulqming@163.com 


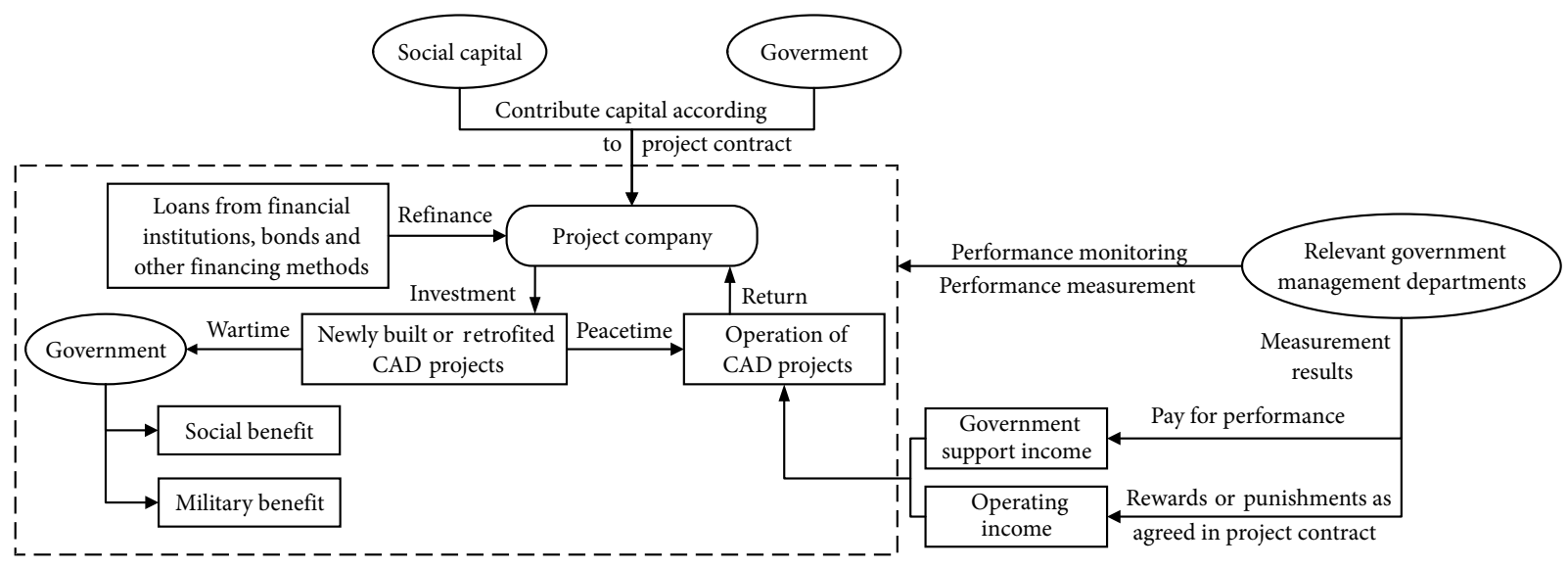

Figure 1. Framework of CAD PPP project

regarding PPP projects (Liu et al., 2015; Villalba-Romero \& Liyanage, 2016), however there is no literature specific on CAD PPP. In addition of being operational, CAD projects also have social and military attributes, thus the performance of CAD PPP projects need to be evaluated separately during peacetime and wartime to ensure the comprehensibility and systematicity of the measurement. Therefore, it is of great significance to study the performance measurement of CAD PPP projects based on analysis the project objectives (economic, social, and military benefits) and characteristics (combination of peacetime and wartime state).

The research objectives of this study are: (1) construct performance measurement indicator system of CAD PPP project to make a comprehensive and objective performance measurement; (2) apply system dynamics approach to model and simulate the performance of CAD PPP project to provide basis for government decision-making; (3) conduct case study to verify the proposed performance measurement method and provide performance improve advices.

The rest of the paper is organized as follows. Section 1 presents a state of art of the related literature. Section 2 illustrates the research methodologies used in the study. The performance measurement model is constructed in Section3, including the construction of performance indicator system, structure analysis and SD model formulation. In Section 4, data from a real case is applied to validate and simulate the SD model proposed in Section 3. Section 5 discusses the simulation results and offers some policy suggestions. Final section summarizes the main findings of this research.

\section{Literature review}

The existing research on PPP project performance measurement mainly focuses on the construction of performance measurement indicator system and performance measurement model. Although the performance goals and influencing factors of different types of PPP projects are different, the principles and ideas to establish the perfor- mance measurement indicator system and the construction of the measurement model are basically the same. Since there are few researches directly on CAD projects, the following review also incorporates researches on the performance measurement of common PPP projects into the analysis to provide a reference for the performance measurement of CAD projects.

\subsection{Literature review on performance measurement indicator system of CAD PPP}

The identification of performance indicators should be based on project performance goals is the consensus of scholars. Many scholars have studied the performance indicator system of PPP projects based on performance target analysis, target influencing factors analysis, key performance indicator (KPI) identification and indicator system framework construction. The research content mainly involves the time span and dimensions of measurement indicators, key driving factors, KPI identification, and indicator weight determination methods.

Augustínová and Daubner (2013) believe that the KPIs of PPP project should involve the entire life cycle of the project. To comprehensively evaluate the performance of the project throughout its life cycle, Li and Liu (2017) established 19 secondary and 45 tertiary performance indicators from five dimensions: environmental attributes, project financing and financial capabilities, project construction control, stakeholder satisfaction, and project sustainability based on balanced scorecard to construct a comprehensive performance measurement indicator system. While identify performance indicators, the most used methods are comprehensive literature analysis, questionnaire surveys and expert interviews. Ostř́žžek (2011) applied literature analysis to identify the influencing factors for VfM, and then qualitatively analyzed the key driving factors. Yuan et al. (2012) constructed a conceptual KPIs to evaluate PPP projects' performance to achieve VfM assessment, and evaluated the importance of the indicators through questionnaire surveys. Based on the stakeholder theory, Yang et al. (2017) used prism method to preliminary determine the performance indicators, then apply 
Delphi method to build a PPP project performance measurement indicator system that covers the entire project life cycle. In order to conduct a comprehensive evaluation of project performance, a logical framework should be established as a criterion for selecting indicators. Sun et al. (2019) established an index logic framework through the horizontal dimension of project cycle framework InputOutput-Outcome-Impact (IOOI) and the vertical dimension of government, private sector, and public, to identify performance indicators of PPP project. Yan et al. (2019) established a performance measurement system for PPP project based on the PSIR (Pressure, State, Influence, and Response) model from the perspective of stakeholders, which consists of 3 dimensions (system layer, subsystem layer and indicator layer) and 53 performance measurement indicators.

\subsection{Literature review on performance measurement method of CAD PPP}

After identifying the performance influencing indicators of CAD PPP, the next step is to carry out a reasonable performance measurement method to improve project performance level during project process and achieve the ultimate strategic goal of PPPs. The accuracy of the performance measurement model will determine the performance measurement level (Yu et al., 2007). The existing research mainly includes performance measurement methods such as structure equation model (Qi \& Kong, 2017), analytic hierarchy process, structured questionnaires, matter element analysis and system dynamics.

Sun et al. (2012) identified three major categories of factors and 18 quantifiable sub-factors that affect project performance, then constructed a structural equation model based on the influencing factors. Their research result shows that the characteristics of a PPP project directly determine its performance, and participant satisfaction and project output effects can best measure the performance level of PPP projects. After constructing the KPI conceptual model, Yuan et al. (2012) used the structural equation model to further analyze the corresponding indicators and study the relationship between different groups of indicators, providing an important reference for the performance optimization of PPP projects. Tang (2019) first constructed a performance measurement indicator system based on the "4E" theory (Economy, Efficiency, Effectiveness and Equity) then apply analytic hierarchy process to determine the weight of each influencing factor and the project performance is evaluated based on comprehensive evaluation of each indicator. Based on KPI performance evaluation theory, Zhao (2009) modularized the core process of PPP project construction and operation then applied matter element analysis to establish a multi-index evaluation model, used correlation functions to realize quantitative rating for project measurement. Although the above methods have taken the weight and relationships between indicators into consideration, but they failed to fully consider the dynamic changes and interrelationships of various indicators throughout the project life cycle. Xue and Zhou (2019) introduced system dynamics method from the perspective of different stakeholders, draw causality diagrams and system flow diagrams to simulate the dynamic relationships between performance measurement indicators, and designed a variety of schemes for simulation to improve the performance management level during project construction and operation period.

\subsection{Limitations of previous research}

At present, there is no research available on the performance measurement of CAD PPP projects, and the existing research on performance measurement of PPP projects mainly focuses on VfM evaluation, main affecting factor identification, measurement indicator system and evaluation model construction. Evaluation methods mainly focus on matter-element method, analytic hierarchy process and structural equation method, there is a lack of researches on the systematization of performance measurement for CAD PPP projects.

In summary, the existing research mainly has the following gaps:

(1) There is no performance measurement indicator system specific for CAD PPP projects, especially to take the differences between indicators during peacetime and wartime states into consideration.

(2) There is a lack of suitable performance evaluation and simulation tools, current researches mainly relying on questionnaire survey and expert interview, there is no integration with objective conditions of the project.

(3) Although many studies have established performance measurement system that covers various factors, but they have neglected the internal connections and logical relationships among them.

$\mathrm{SD}$ is a method for modeling and testing formal mathematical models and computer simulations of complex, nonlinear, and dynamic systems (Yildiz et al., 2020), it can support the policymaking process in systems with increased structural and functional complexity (Pagoni \& Georgiadis, 2020). This study will first establish a performance measurement indicator system for CAD PPP project according to its characteristics then apply SD method to establish effective, systematical and dynamic performance measurement model for CAD PPP project under different states.

\section{Research framework and methodology}

The research is employed to establish the SD-based dynamic performance measurement model for CAD PPP projects. The work flow of the research framework is presented as Figure 2. Performance measurement indicators are preliminary identified from corresponding literatures, laws and regulations based on three-dimensional indicator variable analysis model and 5E principles. The indicators are divided into peacetime and wartime state and each 


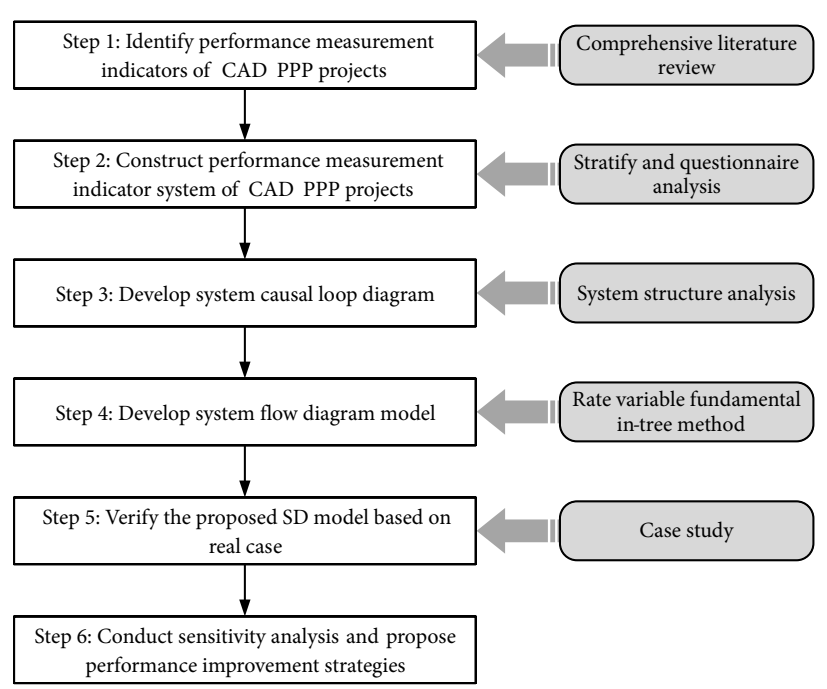

Figure 2. Flow of overall research framework

state is further divided into three dimensions to fit the characteristics of CAD PPP. Structured questionnaire survey is conducted to test the rationality and optimize the indicators to form the CAD PPP performance indicator system.

Considering the complex interrelated structure of the CAD PPP performance indicator system, SD approach is adopted to simulate the relationship among indicators under peacetime and wartime state respectively to effectively conduct performance measurement. The research process employed in the establishment of SD-based performance measurement model includes three steps: 1) system structure analysis and modeling assumptions; 2) conceptualization of indicator relationship using casual loop diagram; 3) development of system flow diagram model to quantify the causal relationship between indicators and perform quantitative analysis. To verify the reliability and accuracy of the proposed SD-based performance measurement model, a case study of a real CAD PPP project is conducted. Finally, sensitivity analysis is applied on key performance influencing indicators to put forward effective countermeasures and suggestions to improve project performance.

\section{Model development and formulation}

\subsection{Construction of performance measurement indicator system for CAD PPP project}

\subsubsection{Indicator system logic framework of CAD PPP project}

In general, the principal stakeholders of a PPP project are government, the private partner, and the general public (Xiong et al., 2015). Different stakeholders have obvious differences in project value orientation based on different interests and preferences during different project evaluation stages (peacetime and wartime). The expected project performance targets, main stakeholders and the project evaluation stages should all be taken into consideration while identifying performance measurement indicators.

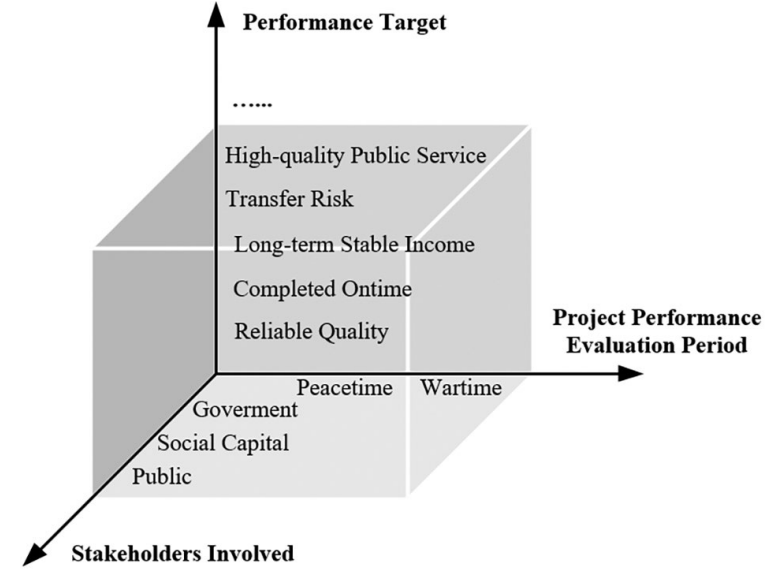

Figure 3. Three-dimensional indicator variable analysis model

To analyze the characteristics of CAD PPP project based on the concept of life cycle, a three-dimensional indicator variable analysis model is constructed as shown in Figure 3.

\subsubsection{Determination of performance measurement indicator system}

The 3E theory (Economy, Efficiency and Effectiveness) from government's financial efficiency audit is widely used to summarize the basic principles of PPP project (Tang, 2019; Yu \& Tang, 2018). With the continuous development of society, Equity and Ecology have been added to form a new $5 \mathrm{E}$ theory. This study combines the $5 \mathrm{E}$ theory and the three-dimensional indicator variable analysis model as logical and criterion framework for selecting indicators. Preliminary performance measurement indicators are identified from academic literatures, corresponding laws and regulations. To construct the preliminary indicator system, literatures related with PPP project performance evaluation are collected and a total number of 20 authoritative literatures are selected based on the number of citations, then indicators that appeared more than 5 times are recorded. Indicators from corresponding laws and regulations are also recorded to include the special characteristics of $\mathrm{CAD}$ projects. CAD projects have different performance states under different social conditions, during peacetime the project is operated by private partner as commercial facilities, while during wartime the project will be handed over to the government while private partner withdrawn from operation. Therefore, the preliminary indicator system is divided into two modes: peacetime and wartime, the two modes are further divided into three layers: subject layer, latitude layer and indicator layer.

Because there are few researches on CAD project at present, it is necessary to further research and judge the identified indicators through experts and practitioners. A questionnaire survey is conducted among the stakeholders (Government departments, Government and investor project company, Consulting unit, University research institutions, Financial institutions and General contractors) of CAD PPP projects to test the rationality and optimize the previously identified preliminary indicators. A total number of 600 questionnaires were distributed and 536 
questionnaires were returned, of which 225 were valid. SPSS 22.0 is used to process data and conduct reliability analysis. The calculated Cronbach's $\alpha$ value is 0.945 , the KMO value of this questionnaire is 0.834 , while the Bartlett test value is significant at $\mathrm{P}=0$, which indicates that the data is valid for further discussion. Data analysis is implied to eliminate the less important and controversial indicators according to the survey results. After optimization, there are 30 performance measurement indicators for CAD-PPPs under peacetime condition and 9 under wartime condition. The optimized indicator system is illustrated in Table 1 and Table 2.

Table 1. Performance measurement indicator system of CAD PPP project (peacetime)

\begin{tabular}{|c|c|c|c|}
\hline $\begin{array}{c}\text { Evaluation } \\
\text { subject }\end{array}$ & $\begin{array}{l}\text { Evaluation } \\
\text { dimension }\end{array}$ & Evaluation indicator & Indicator description \\
\hline \multirow{16}{*}{$\begin{array}{l}\text { Private } \\
\text { partner } \\
\text { (A) }\end{array}$} & \multirow{2}{*}{$\begin{array}{l}\mathrm{A}_{1} \text { Financial } \\
\text { and financing } \\
\text { capabilities }\end{array}$} & $\begin{array}{l}\mathrm{A}_{11} \text { Rationality of } \\
\text { financing structure }\end{array}$ & $\begin{array}{l}\text { Choose a financing structure with lower financing costs and lower financing } \\
\text { risks based on actual conditions. }\end{array}$ \\
\hline & & $\begin{array}{l}\mathrm{A}_{12} \text { Effectiveness of } \\
\text { financial monitoring }\end{array}$ & $\begin{array}{l}\text { Effective supervision of private sector's financing, construction and } \\
\text { operation costs. }\end{array}$ \\
\hline & \multirow{4}{*}{$\begin{array}{l}\mathrm{A}_{2} \text { Project } \\
\text { construction } \\
\text { management }\end{array}$} & $\begin{array}{l}\mathrm{A}_{21} \text { Quality } \\
\text { inspection indicator }\end{array}$ & $\begin{array}{l}\text { On-site safety measures are taken, construction site layout is reasonable, } \\
\text { material stacking meets requirements. }\end{array}$ \\
\hline & & $\begin{array}{l}\mathrm{A}_{22} \text { Progress control } \\
\text { indicator }\end{array}$ & $\begin{array}{l}\text { The actual progress at the time of evaluation is ahead or lagging compared } \\
\text { to the planned progress. }\end{array}$ \\
\hline & & $\begin{array}{l}\mathrm{A}_{23} \text { Cost control } \\
\text { index }\end{array}$ & $\begin{array}{l}\text { Whether the cost of the completed project is reasonable, and whether the } \\
\text { cost is overrun or saved compared to the planned cost. }\end{array}$ \\
\hline & & $\begin{array}{l}\mathrm{A}_{24} \text { Construction } \\
\text { safety accident rate }\end{array}$ & $\begin{array}{l}\text { Whether there were any safety accidents during the construction period, the } \\
\text { number and level of safety accidents. }\end{array}$ \\
\hline & \multirow{4}{*}{$\begin{array}{l}\mathrm{A}_{3} \text { Operation } \\
\text { stage } \\
\text { management }\end{array}$} & $\begin{array}{l}\mathrm{A}_{31} \text { Operational } \\
\text { safety indicators }\end{array}$ & $\begin{array}{l}\text { Whether the number of days of safe operation in an evaluation cycle meets } \\
\text { the requirements of the contract. }\end{array}$ \\
\hline & & $\begin{array}{l}\mathrm{A}_{32} \text { Operational } \\
\text { technical reliability }\end{array}$ & $\begin{array}{l}\text { In an evaluation period, whether the technology used in completed project } \\
\text { facilities or equipment is reliable, advanced and innovative. }\end{array}$ \\
\hline & & $\begin{array}{l}\mathrm{A}_{33} \text { Operational cost } \\
\text { rationality }\end{array}$ & $\begin{array}{l}\text { Whether the project operating cost is reasonable, and whether it is } \\
\text { overspending or saving compared with the planned operating cost. }\end{array}$ \\
\hline & & $\begin{array}{l}\mathrm{A}_{34} \text { Operational } \\
\text { efficiency }\end{array}$ & $\begin{array}{l}\text { In an evaluation period, whether the operation management is regular, } \\
\text { effective and in line with the planned operation frequency. }\end{array}$ \\
\hline & \multirow[t]{3}{*}{$\begin{array}{l}\mathrm{A}_{4} \text { Project } \\
\text { output benefit }\end{array}$} & $\begin{array}{l}\mathrm{A}_{41} \text { Rationality of } \\
\text { project rate of return }\end{array}$ & $\begin{array}{l}\text { The income during the project operation stage is reasonable, and whether } \\
\text { the income ability of the project investment meets the contractual standards. }\end{array}$ \\
\hline & & $\mathrm{A}_{42}$ Tax contribution & The project's contribution to local taxation in an evaluation period. \\
\hline & & $\begin{array}{l}\mathrm{A}_{43} \text { Achieve output/ } \\
\text { turnover }\end{array}$ & $\begin{array}{l}\text { During an evaluation period, the output value or turnover of the project } \\
\text { operation. }\end{array}$ \\
\hline & \multirow{3}{*}{$\begin{array}{l}A_{5} \text { Effectiveness } \\
\text { of risk } \\
\text { management } \\
\text { system }\end{array}$} & $\begin{array}{l}\mathrm{A}_{51} \text { Technical } \\
\text { environmental risk }\end{array}$ & $\begin{array}{l}\text { Risks arising from the development of science and technology, changes in } \\
\text { production methods, and changes in the regional environment. }\end{array}$ \\
\hline & & $\mathrm{A}_{52}$ Economic risk & $\begin{array}{l}\text { The possibility of economic losses due to the uncertainty of the economic } \\
\text { environment. }\end{array}$ \\
\hline & & $\mathrm{A}_{53}$ Contract risk & $\begin{array}{l}\text { The risk of the contract itself and the risk of the contract performance } \\
\text { process. }\end{array}$ \\
\hline \multirow{5}{*}{$\begin{array}{l}\text { Govern- } \\
\text { ment (B) }\end{array}$} & \multirow{3}{*}{$\begin{array}{l}\mathrm{B}_{1} \text { Project input } \\
\text { stage }\end{array}$} & $\begin{array}{l}\mathrm{B}_{11} \text { Timely arrival of } \\
\text { funds }\end{array}$ & $\begin{array}{l}\text { Whether the actual government investment in place is consistent with the } \\
\text { time and amount scheduled in the contract. }\end{array}$ \\
\hline & & \begin{tabular}{|l|}
$\mathrm{B}_{12}$ Reasonable \\
investment plan and \\
return time node
\end{tabular} & $\begin{array}{l}\text { Whether the time node setting of the investment plan is reasonable and } \\
\text { whether the preset evaluation indicators are achieved. }\end{array}$ \\
\hline & & $\begin{array}{l}\mathrm{B}_{21} \text { Contribution rate } \\
\text { of urban green space }\end{array}$ & Increase in urban green space due to new projects. \\
\hline & \multirow{2}{*}{$\begin{array}{l}\mathrm{B}_{2} \text { Project } \\
\text { operation stage } \\
\text { management } \\
\text { (Peacetime) }\end{array}$} & $\begin{array}{l}\mathrm{B}_{22} \text { Degree of } \\
\text { coordination in } \\
\text { urban construction }\end{array}$ & $\begin{array}{l}\text { The degree to which the internal elements of the system are in harmony } \\
\text { with each other during development. }\end{array}$ \\
\hline & & $\begin{array}{l}\mathrm{B}_{23} \text { Degree of } \\
\text { underground space } \\
\text { development }\end{array}$ & $\begin{array}{l}\text { The extent to which underground building space is used to improve urban } \\
\text { functions and urban environmental quality. }\end{array}$ \\
\hline \multirow{3}{*}{$\begin{array}{l}\text { General } \\
\text { Public (C) }\end{array}$} & \multirow{3}{*}{$\begin{array}{l}\mathrm{C}_{1} \text { Project } \\
\text { service quality }\end{array}$} & $\begin{array}{l}\mathrm{C}_{11} \text { Investment } \\
\text { and employment } \\
\text { improvement }\end{array}$ & $\begin{array}{l}\text { Increased amount of investment and employment in the city due to new } \\
\text { projects. }\end{array}$ \\
\hline & & $\begin{array}{l}\mathrm{C}_{12} \text { New parking } \\
\text { spaces }\end{array}$ & Increase in the number of urban parking spaces due to new projects. \\
\hline & & $\mathrm{C}_{13}$ User satisfaction & $\begin{array}{l}\text { Comprehensive satisfaction with the products or services provided by public } \\
\text { projects and the impact of projects. }\end{array}$ \\
\hline
\end{tabular}


Table 2. Performance measurement indicator system of CAD PPP project (wartime)

\begin{tabular}{|c|c|c|c|}
\hline $\begin{array}{l}\text { Evaluation } \\
\text { subject }\end{array}$ & $\begin{array}{l}\text { Evaluation } \\
\text { dimension }\end{array}$ & Evaluation indicator & Indicator meaning \\
\hline \multirow[t]{7}{*}{$\begin{array}{l}\text { Government } \\
\text { (D) }\end{array}$} & \multirow{5}{*}{$\begin{array}{l}\mathrm{D}_{1} \text { Project } \\
\text { operation stage } \\
\text { management } \\
\text { (wartime) }\end{array}$} & $\mathrm{D}_{11}$ Responding speed & $\begin{array}{l}\text { The ability to promptly report and transfer resettlement personnel and } \\
\text { materials in event of war. }\end{array}$ \\
\hline & & $\begin{array}{l}\mathrm{D}_{12} \text { Facility delivery } \\
\text { speed }\end{array}$ & $\begin{array}{l}\text { The speed at which equipment is inspected and repaired to make the } \\
\text { facility available during peace-to-war transformation. }\end{array}$ \\
\hline & & $\mathrm{D}_{13}$ Facility availability & The degree of combat readiness of CAD facilities when disaster strikes. \\
\hline & & $\begin{array}{l}\mathrm{D}_{14} \text { Technology transfer } \\
\text { rate }\end{array}$ & $\begin{array}{l}\text { The transfer speed of technologies such as airtight doors and ventilation } \\
\text { during peace-to-war transformation. }\end{array}$ \\
\hline & & $\begin{array}{l}\mathrm{D}_{15} \text { Peace-to-war } \\
\text { conversion ratio }\end{array}$ & $\begin{array}{l}\text { The proportion of the combat readiness area in the project to the total } \\
\text { project area. }\end{array}$ \\
\hline & \multirow{2}{*}{$\begin{array}{l}\mathrm{D}_{2} \text { Effectiveness } \\
\text { of risk } \\
\text { management } \\
\text { system }\end{array}$} & $\begin{array}{l}\mathrm{D}_{21} \text { Protection system } \\
\text { completeness }\end{array}$ & $\begin{array}{l}\text { Whether the protection in the basement of CAD works is in place and } \\
\text { the quality is qualified. }\end{array}$ \\
\hline & & $\mathrm{D}_{22}$ Political risk & The uncertainty of the project due to the political environment. \\
\hline \multirow[t]{2}{*}{$\begin{array}{l}\text { General } \\
\text { public (E) }\end{array}$} & \multirow[t]{2}{*}{$\begin{array}{l}\mathrm{E}_{1} \text { Social } \\
\text { benefits }\end{array}$} & $\begin{array}{l}\mathrm{E}_{11} \text { Additional hidden } \\
\text { area }\end{array}$ & Prevention area provided by the project during wartime. \\
\hline & & $\begin{array}{l}\mathrm{E}_{12} \text { Additional number } \\
\text { of hidden populations }\end{array}$ & Number of hidden populations provided by the project during wartime. \\
\hline
\end{tabular}

\subsection{System structure analysis}

System structure analysis is the theoretical basis of SD modeling, which includes defining system boundaries, modeling assumptions and constructing causalities and feedbacks (Hu et al., 2020). The system causal loop diagram embodies the systematic visualized framework characterizing the dynamic drivers of a set of particular decisions can clearly describe the concept of interdependence between systems (Walters et al., 2016).

\subsubsection{Modeling assumptions}

This research proposes the following hypotheses:

(1) Assuming when private partner participates in a PPP project, their degree of effort is proportional to their investment return within a certain range, and the private partner will make the greatest effort to promote the success of the project;

(2) The government's attention directly determines the success of PPP project, thus government investment can be used as a measurement indicator. Assuming the government will make every effort to promote the success of the PPP project, local policy support is available and government credit is guaranteed;

(3) To ensure the project progress, the participants use negotiation to resolve problems and disputes, and reasonable agreement can be reached every time.

\subsubsection{Peacetime causal loop diagram}

Because government, private partner, and the public will influence and interact with each other, it is necessary to combine the interests of all stakeholders to improve the overall performance of CAD PPP. The peacetime state is divided into three sub-systems (government, private partner, and public), and each sub-system is further divided into different dimensions as discussed in the indicator system section. Some auxiliary variables are also added to fit the actual needs of CAD PPP project. The indicators from three subsystems are connected and independent with each other, integrating into 16 causal feedback loops to form peacetime causal loop diagram as shown in Figure 4. The cause and effect relationship can be traced by following the direction of the arrows, this indicates whether there is an increasing or decreasing relationship between two variables, which was denoted by a polarity, i.e., positive "+" or negative "-" on the arrow (Xu et al., 2012). Vensim PLE simulation software is used for modeling and simulation in this study.

\subsubsection{Wartime causal loop diagram}

During wartime, the owner and operator of CAD PPP projects are transferred from private partner to the government. Therefore, the effect of transfer from peacetime mode to wartime mode should be taken into consideration when measure project performance. Peacetime to wartime transfer effect including three indicators: Transfer speed, Facility availability, and Peace-to-war conversion ratio. Transfer speed can be divided into Equipment delivery speed, Technology handover speed, and Disaster response speed. Whether the effect of peace-to-war transformation is fully utilized also determines the government's risk in operating and maintaining of the project. Finally, risk management and control are also used as indicators for project output effects, which are divided into Operation and maintenance risk and Political risk. There are 6 loops in the causal loop diagram of CAD PPP projects under wartime conditions, as shown in Figure 5. 


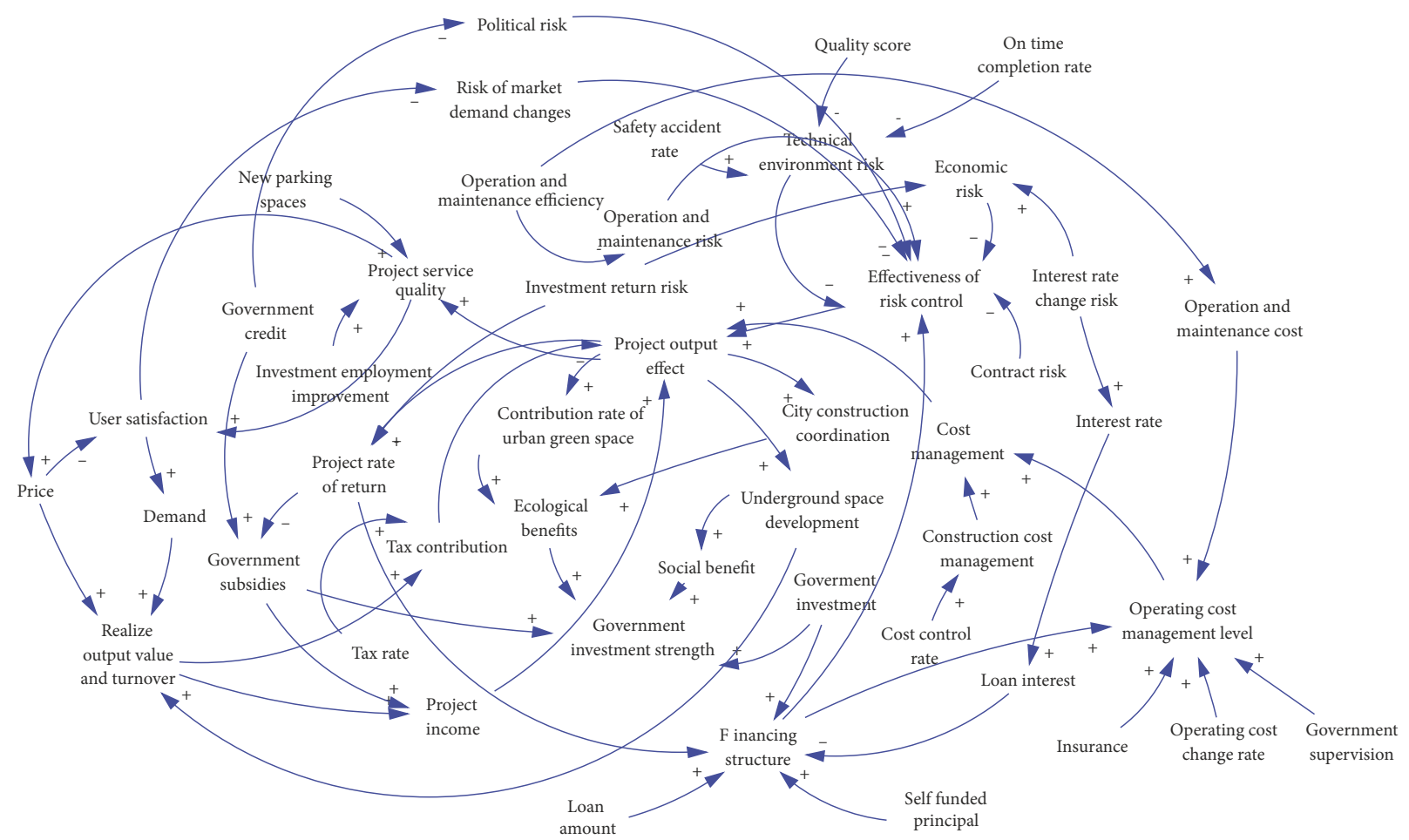

Figure 4. CAD PPP project performance measurement system causality diagram

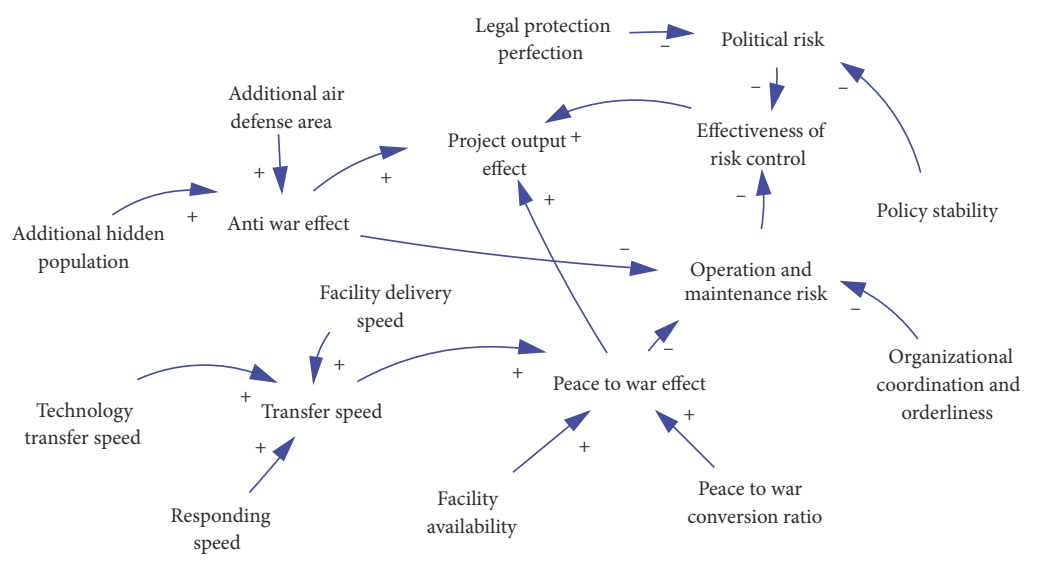

Figure 5. CAD PPP project performance measurement system causality diagram

\subsection{Development of system flow diagram model}

\subsubsection{Rate variable fundamental in-tree model and quantitative equations}

Rate variable fundamental in-tree method is used to construct the sub-system with the rate variable as the root of the tree (Jia \& Wu, 1998), and then analyze sequentially to transform the proposed causal loop diagram into a stock-flow map configured with 2 constant variables, 3 level variables, 6 rate variables, and 43 auxiliary variables. The inflow and outflow systems are modeled separately for each flow rate variable, and the quantitative equations are shown as in Table 3.

\subsubsection{System flow diagram for peacetime and wartime}

There are 17 quantitative equations for peacetime state, the system flow diagram is shown in Figure 6. During peacetime, the model is developed into two parts: Project economic benefits and Government benefits, the two parts will influence and interact with each other. The performance of government and the private partner will affect the performance of the entire project. At the same time, the improvement of project performance level will also promote the behavior of private partner and government.

During wartime, the CAD PPP project is operated by government. Government revenue increment, Government risk increment are used as rate variables and Additional hidden population, Additional hidden area is used as auxiliary variables. Wartime system flow diagram is shown as Figure 7.

\section{Model simulation and analysis: A case study}

To verify the effectiveness of the proposed SD-based model, a comprehensive stadium CAD PPP project is used as 
Table 3. Rate variable fundamental in-tree model and quantitative equations

Quantitative equations

(1) Project income $=$ Government investment + Operating income + Government subsidies

(2) Operating income $=$ Demand $\times$ Price

(3) Project expenditure $=$ Tax + Social capital investment + Risk control cost + Operating cost + Construction cost

(4) Taxes $=$ Operating income $\times$ Tax rate

(5) Social capital investment $=$ Loan amount + Self-raised capital + Loan amount $\times$ Interest rate

(6) Interest rate change $=$ Interest rate $\times$ Random factor interest rate $\times$ Random factor

(7) Risk control cost $=\mathrm{a} \times$ Interest rate change $\times$ Loan amount $+\mathrm{b} \times$ Operating cost change rate $\times$ Operating cost $+\mathrm{c} \times$ Technical environment risk $+\mathrm{d} \times$ Demand $\times$ Price change coefficient (where $\mathrm{a}, \mathrm{b}, \mathrm{c}, \mathrm{d}$ is the proportion of each variable in the cost of risk control, which can be calculated based on expert scores)

(8) Operating cost $=$ Management cost + Insurance cost

(9) Project economic benefit $=$ Project income - Project expenditure

(10) Government income increment during peacetime $=$ Ecological benefit + Social benefit + Tax

(11) Ecological benefit $=$ Project green area $\div$ Project area

(12) Project service quality = Additional parking space + Operating cost $\div$ Project expenditure + Operating income

(13) User satisfaction $=x \times$ Project service quality $+y \times$ Price (where $x, y$ are coefficients and $x+y=1$, the specific assignment will be defined during simulation process)

(14) Social benefit $=($ Project income - Project cost $) \times$ User satisfaction

(15) $\mathrm{Tax}=$ Operating income $\times$ Tax rate

(16) Government investment increment = Government investment - Government subsidies

(17) Government revenue $=$ Government revenue increment - Government investment increment

(18) Peace-to-war effect $=$ Peace-to-war area $\div$ Project area + Transfer speed + Number of available equipment $\div$ Total number of equipment

(19) Transfer speed $=\alpha \times$ Response speed $+\beta \times$ Equipment delivery speed $+\gamma \times$ Technology handover speed (where $\alpha, \beta, \gamma$ are coefficients, the specific assignment will be defined during simulation process

(20) Anti-war effect $=$ Additional hidden area + Additional hidden population

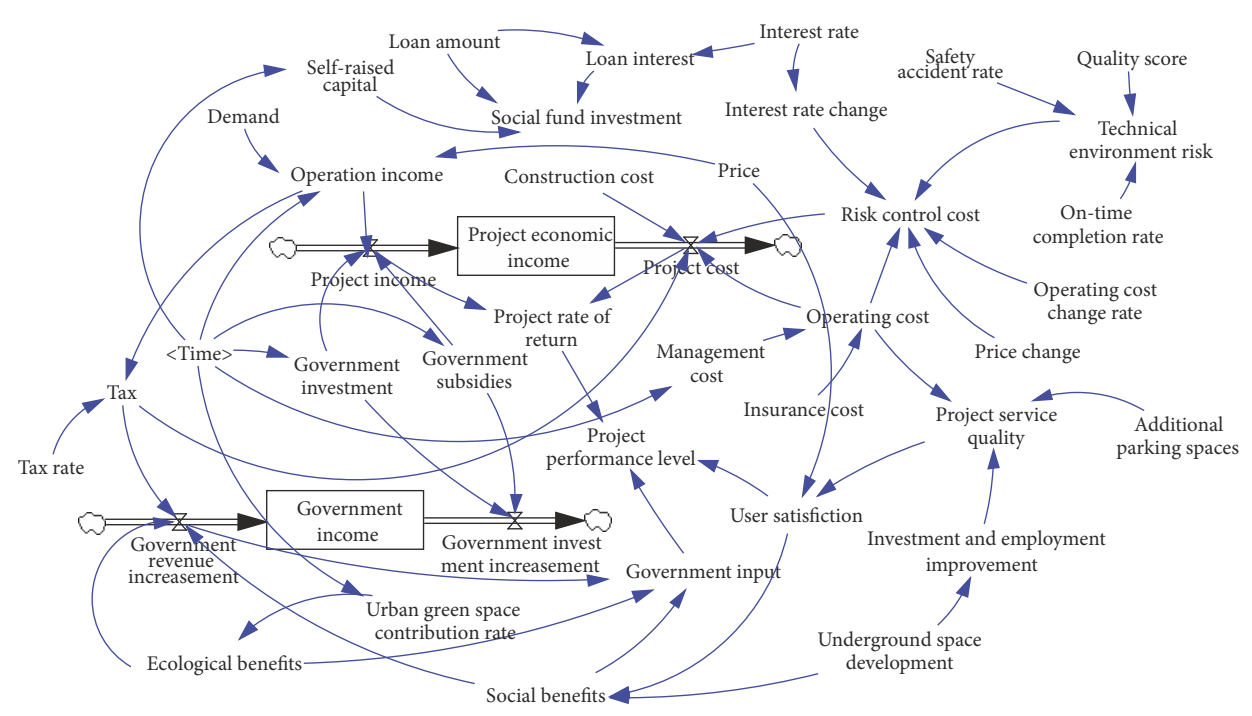

Figure 6. Peacetime system flow diagram

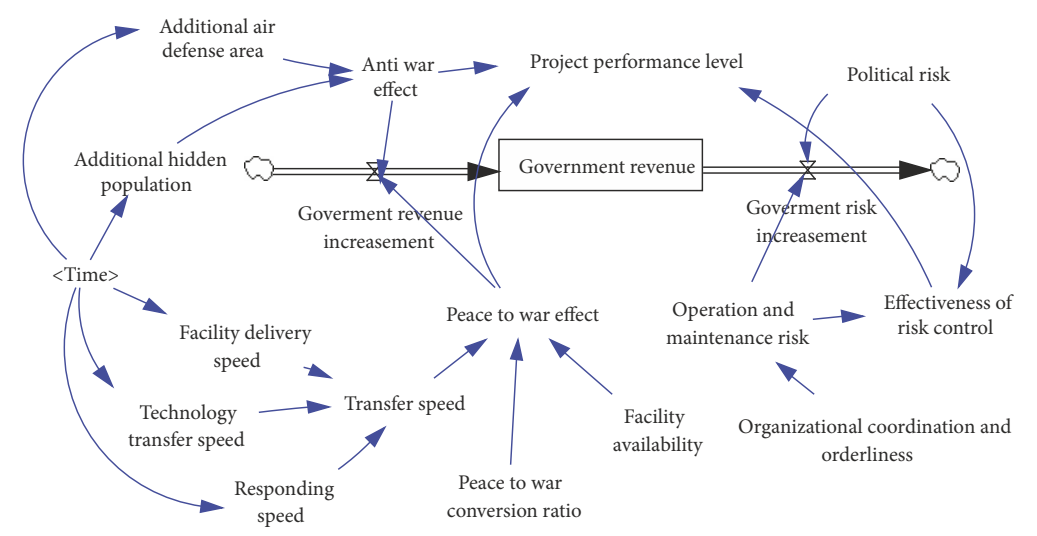

Figure 7. Wartime system flow diagram 
a case to perform performance measurement and simulation. The relevant data and information are obtained from the network, government work reports and project VfM reports. While evaluating the simulation, the validity of the SD model established previously will be tested according to the real information of the project.

\subsection{Case profile}

The total land area of the project is $39,899.41$ square meters, and the total investment is 220 million yuan. The project facilities are divided into two parts: ground stadium part and underground CAD part. During peacetime, the underground space is used as commercial operations and parking lot. While during wartime, it's a shelter for second-class personnel and a comprehensive CAD material warehouse. The project assets belong to the government and government transfers the franchise rights of the stadium and underground space to private partner with a one-time transfer fee. During franchise period, the private partner is responsible for the development, operation and maintenance of the project facilities in accordance with the franchise agreement.

The construction period of the project is 3 years and the concession period is 20 years. The total operation income is the revenue sum of ground stadium part and underground CAD space. Assuming the project operating load is $50 \%$ and $75 \%$ for the first two years, and reaches full load in the third year, the operating income will increase by $3 \%$ every year thereafter. Table 4 shows the project operating income during first ten years of the franchise period.

It is estimated that the project annual operating cost in normal years is 1 million yuan. Except for the overhaul fund, other costs and expenses will change according to the actual operation of the project. After the project is fully operational, the operation and maintenance cost will increase at an average annual rate of $1 \%$. Related operating costs, operating income and feasibility gap subsidies are shown in Table 5.

\subsection{Model validation and simulation}

\subsubsection{Model validation}

The purpose of model verification is to determine whether the structure of the model can replicate a real system (Ansari, 2019). Common model errors mainly include two types, the first one is input error of internal equation variables. The main reasons are: no initial values provided for state variables; the function form is not used correctly; the relationship between auxiliary variables and other variables is uncertain. The other type is variables in the model are not fully utilized. The main reasons are lack of connection between variables; some variables between connected variables are not used (Yildiz et al., 2020). According to Vensim software build-in test, the model is valid and can be simulated.

\subsubsection{Model simulation}

According to the project profile, the first three years are construction period, from the fourth year onwards, the project has obtained benefits through operating income and feasibility gap subsidies. The risk cost of the project is 21.56 million yuan in the first year and 100,000 yuan every year thereafter.

(1) Peacetime simulation results from the perspective of private partner

The private partner cares most about the economic indicators of the project. According to the simulation results as shown in Figure 8 to 11, the project income begins to grow on the third year, which is consistent with the project actual situation. Economic benefits of the project have grown steadily from the 15th year to the 11th year and project rate of return grows after the end of construction period and fluctuate around 7 percent afterwards. The concession period of this project is planned to be 20 years and the operating right transfer fee is 170 million yuan, so after the end of the franchise right transfer, the private partner will enjoy profit.

Table 4. Project operating income during first ten years of the franchise period (unit: ten thousand yuan)

\begin{tabular}{|l|c|c|c|c|c|c|c|c|c|c|}
\hline \multirow{2}{*}{\multicolumn{1}{c|}{ Project }} & \multicolumn{10}{c|}{ Operating period } \\
\cline { 2 - 11 } & 1 & 2 & 3 & 4 & 5 & 6 & 7 & 8 & 9 & 10 \\
\hline Non-CAD operating income & 384.00 & 576.00 & 768.00 & 791.04 & 814.77 & 839.21 & 864.39 & 890.32 & 917.03 & 944.54 \\
\hline CAD operating income & 96.00 & 144.00 & 192.00 & 197.76 & 203.69 & 209.80 & 216.10 & 222.58 & 229.26 & 236.14 \\
\hline Total project operating income & 480.00 & 720.00 & 960.00 & 988.80 & 1018.46 & 1049.01 & 1080.49 & 1112.90 & 1146.29 & 1180.68 \\
\hline
\end{tabular}

Table 5. Feasibility gap subsidies budget table (unit: ten thousand yuan)

\begin{tabular}{|c|c|c|c|c|c|c|c|c|c|c|}
\hline \multirow{2}{*}{ Project } & \multicolumn{10}{|c|}{ Operating period } \\
\hline & 1 & 2 & 3 & 4 & 5 & 6 & 7 & 8 & 9 & 10 \\
\hline Operating cost & 50 & 75 & 100 & 101 & 102 & 103 & 104 & 105 & 106 & 107 \\
\hline Operating income & 48 & 720 & 960 & 989 & 1018 & 1049 & 1080 & 1113 & 1146 & 1181 \\
\hline Feasibility gap subsidies & 2033 & 1955 & 1884 & 2007 & 2137 & 2276 & 2422 & 2577 & 2742 & 2916 \\
\hline
\end{tabular}




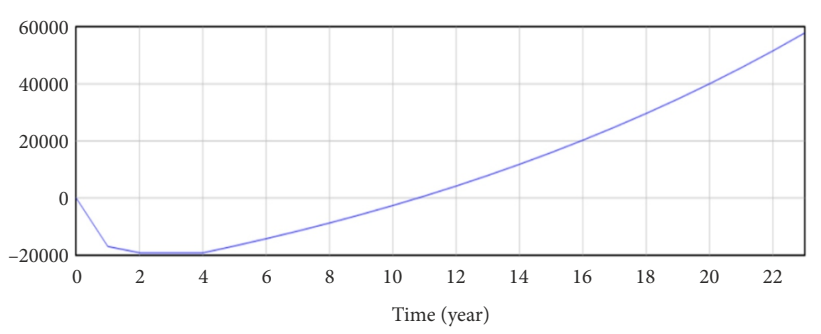

Figure 8. Simulation results of project economic benefits (unit: ten thousand yuan)

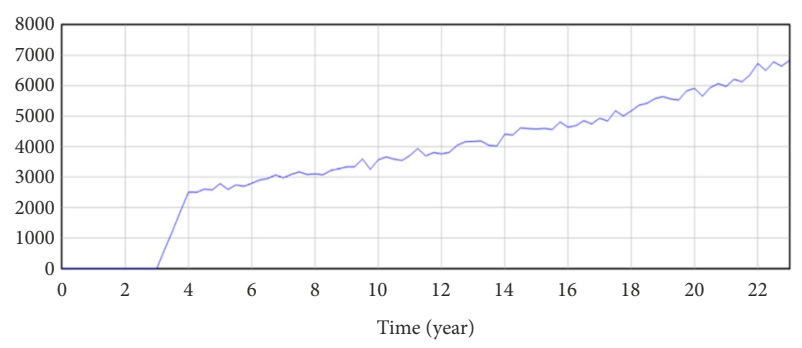

Figure 9. Simulation results of project income (unit: ten thousand yuan)

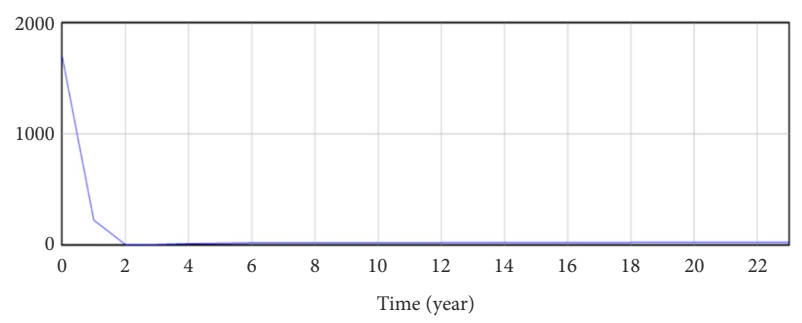

Figure 10. Simulation results of project cost (unit: ten thousand yuan)

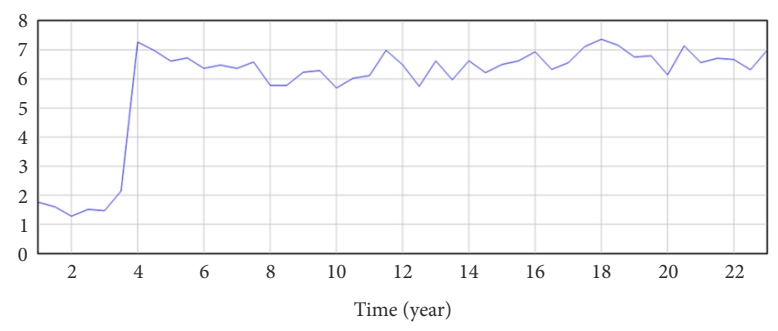

Figure 11. Simulation results of project rate of return (unit: percent)

(2) Peacetime simulation results from the perspective of government

Government revenues depend on taxes, social benefits and improvements in investment and employment brought by the development of CAD projects, which have gradually increased during project operations. Since the stadium is a public welfare project, the income is not enough to fully cover its operating costs and a reasonable return for private partner. Therefore, government will provide a 10 -year feasibility gap subsidy for this project starting from the fourth year.

According to the simulation results as shown in Figures 12 to 15 , from the 7 th year, the increase in government revenue is greater than the increase in government investment because of the increase in the project's social benefits and operating income.

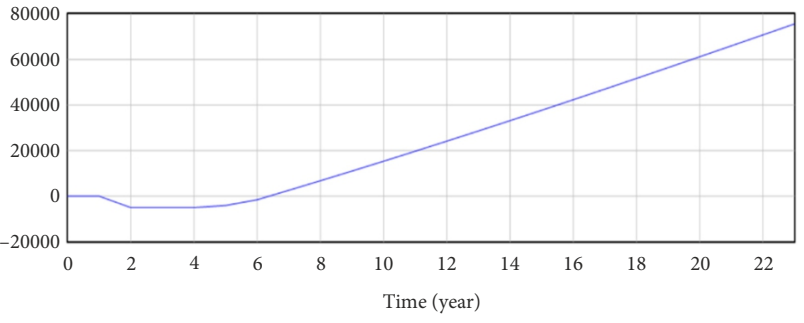

Figure 12. Simulation result for government revenue (unit: ten thousand yuan)

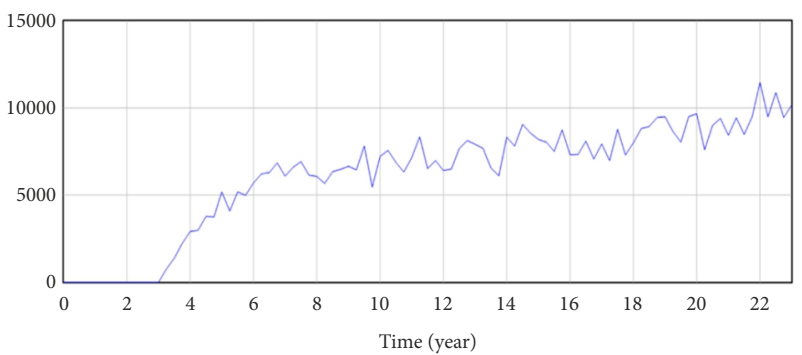

Figure 13. Simulation result for government revenue increment (unit: ten thousand yuan)

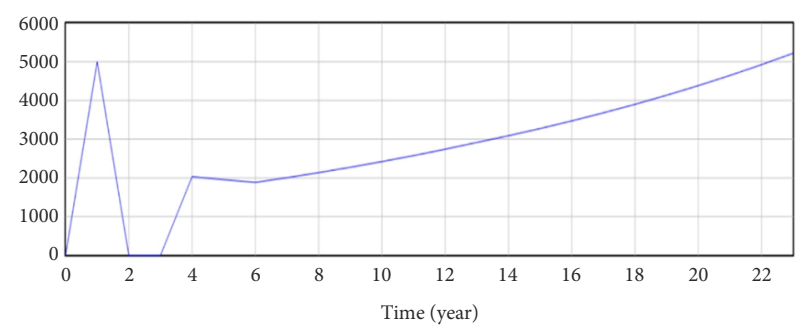

Figure 14. Simulation result for government investment increment (unit: ten thousand yuan)

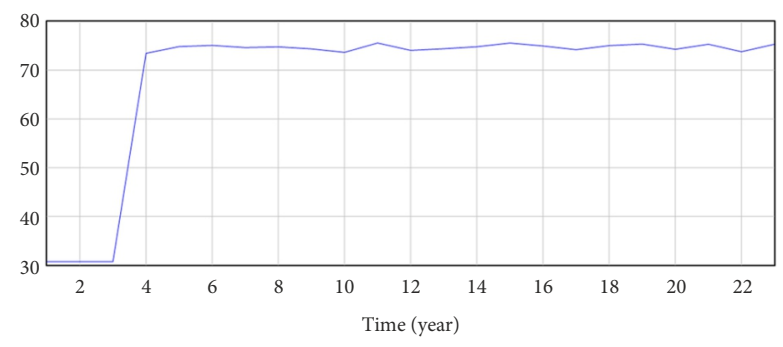

Figure 15. Simulation result for user satisfaction (unit: percent)

(3) Peacetime simulation results from the perspective of public

The public is the user of CAD PPP projects, their evaluation is an important basis for judging the project performance. The public mainly cares about the quality of the project and the price of products and services. According to the simulation results of User satisfaction, the user satisfaction is poor during first 3 years because the public is disturbed by the project construction. After the project was put into use, the user satisfaction increased and fluctuate around $75 \%$.

The model simulation results are consistent with the investment return and benefits described in the project feasibility report, which shows that the model is effective, 
therefore the performance simulation of wartime state can be performed.

(4) Wartime project performance and flow rate variables simulation results

Due to the contingency of the wartime system, entropy method is used to determine the weight of system influencing factors. In the indicator data matrix $X$, the greater the difference in indicator values, the smaller the information entropy, and the greater the weight of the indicator. Entropy method can eliminate the influence of the subjective factors on the weight of each influencing factor (Ji et al., 2019), which can make the evaluation of the system more fair and objective.

Assuming there are $m$ evaluation objects, $n$ evaluation indicators and the original data matrix based on collected data is $\left(X_{i j}\right)_{m \times n}$, where is $X_{i j}$ is the value of the $j$ indicator of the $i$ object. The specific process is as follows.

a) Normalization: calculate the proportion of the $i$-th object under the $j$-th indicator, and the standard matrix obtained after processing is:

$$
\left(P_{i j}\right)_{m \times n} \text {, where } P_{i j}=\frac{X_{i j}}{\sum_{i=1}^{n} X_{i j}}(j=1,2, \ldots, m) \text {; }
$$

b) Calculate entropy:

$$
\begin{aligned}
& e_{j}=-k \times \sum_{1=1}^{n} P_{i j} \ln \left(P_{i j}\right), \\
& \text { where } k>0, e_{j} \geq 0, k=\frac{1}{\ln m}, 0 \leq e \leq 1 ;
\end{aligned}
$$

c) Calculate difference coefficient:

$$
g_{i}=1-e_{j}
$$

d) Calculate weight:

$$
\theta_{j}=\frac{g_{i}}{\sum_{j=1}^{m} g_{i}}, \text { where } j=1,2, \ldots, m .
$$

The functional expressions of variable equations after weight assignment based on entropy method are listed as below.

Peace-to-war transfer speed $=0.3329 \times$ Disaster response speed $+0.3324 \times$ Technology transfer speed $+0.3347 \times \mathrm{Fa}$ cility delivery speed.

Peace-to-war transfer effect $=0.5002 \times$ Additional CAD area $+0.4998 \times$ Additional hidden population .

Effectiveness of risk control $=0.3993 \times$ Political risk + $0.6007 \times$ Operation and maintenance risk.

Government revenue increment $=0.7143 \times$ Peace-to-war transfer effect $+0.2857 \times$ Anti-war effect.

Project performance level $=0.5655 \times$ Peace-to-war transfer effect $+0.2422 \times$ Anti-war effect $+0.1923 \times$ Risk control effectiveness.

Input the variable equations into the model, facility delivery time is set as 30 days, and the simulation is start from the occur of disaster, the project performance level under wartime condition is shown as Figure 16.

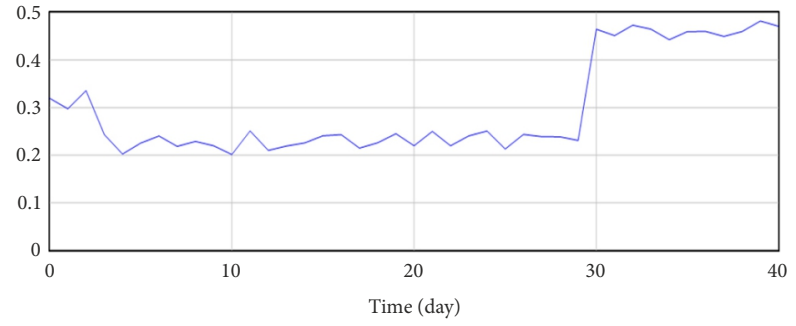

Figure 16. Project performance level under wartime condition

Figure 16 implies that the CAD PPP project cannot be put into use before the delivery of the project facilities, and the project performance level improves after the peace-to-war transformation completes.

\subsection{Sensitivity analysis}

Sensitivity analysis is applied to analyze and compare influence on the output results by changing some parameters (Lee \& Stedinger, 2009). In this article, changes are applied on key indicators to analyze the main factors' influence on project performance, and put forward effective countermeasures and suggestions to improve project performance.

\subsubsection{Sensitivity analysis for peacetime condition}

During peacetime, both government and private partner are important participants during construction and operation of CAD PPP project, while the public is user and beneficiary of project. The private partner cares most about the Project economic benefits, from the perspective of project economic benefits, the main factors affecting project performance are project operating cost and the project financing structure. The government is an important promoter of the project, because due to the project characteristics, it is difficult for private partner to obtain sufficient profits during the operating period. Thus, government investment will directly affect its economic benefits, Government investment is related to Government subsidies and Tax rate. Public sector is the user of the project, their evaluation is an important part of project performance, factors affecting User satisfaction are Project service quality and Price. Based on the analysis above, this section will conduct sensitivity analysis on Operation cost, Government investment, Tax rate, Government subsidies and User satisfaction.

\section{(1) Operating cost}

When Operating cost is increased by $5 \%$, there is an increase in the project performance curve. If it drops by $5 \%$, the result is reversed. We can gather from Figure 17 that during the operation of CAD PPP projects, an appropriate increase in Operating cost can effectively improve the project maintenance efficiency therefore increase user satisfaction.

\section{(2) Government investment}

When Government investment reduces by 20 million, the economic benefits of the project fell sharply as shown 
in Figure 18. If the government increases investment by 20 million, the project will make profits one year ahead of schedule, which indicates increase in project's overall economic benefits. The result shows that government plays a pivotal role in the construction and operation of CAD PPP projects, and determining a reasonable project return mechanism is one of the key factors for project success.

\section{(3) Tax rate}

As shown in Figure 19, if the tax rate is reduced by $5 \%$, the project performance increases compared with the initial curve, if it increases by $5 \%$, the result is reversed. The results show that giving corresponding preferential policies, such as reducing or exempting the tax on private partner can improve project performance.

\section{(4) Government subsidies}

To ensure the smooth operation of the project, Government subsidies for this project is the feasibility gap subsidy. The simulation results in Figure 20. shows that an appropriate increase in Government subsidies can effectively improve project performance, reduce the pressure on the private partner side, as well as improve public satisfaction.

\section{(5) User satisfaction}

According to the simulation model, user satisfaction depends on Project service quality and Price. As shown in Figures 21 and 22, if Project service quality increased by $5 \%$, User satisfaction will increase by around 3\%; if Project service quality decreased by $5 \%$, User satisfaction will decrease by $3 \%$, respectively. Price has a negative correlation with User satisfaction, if Price increased by 5\%, User satisfaction will decrease by around $2 \%$. The simulation results show that improve Project service quality and reduce project price can increase User satisfaction as well as promote project performance. The Project service quality is affected by the operation and maintenance of the private partner's management level; therefore, the private partner should appropriately increase operating costs to improve the project quality to increase User satisfaction.

\subsubsection{Sensitivity analysis for wartime condition}

The peace-to-war transfer speed of CAD project is an important indicator to determining whether the project can reflect military benefits, and Facility delivery time is the key indicator that affects the Transfer speed. The hidden area and the number of hidden people provided by CAD project are also important indicators for evaluating its military benefit. Therefore, this section will conduct sensitivity analysis on Facility delivery time and Additional hidden area.

\section{(1) Facility delivery time}

According to Figure 23, if Facility delivery time is shortened by 5 days, which means the CAD project can be used in advance, the operation and maintenance risks can be reduced, and project organization and coordination can be improved. If Facility delivery time is extended by 5 days, it will increase the risk of personnel transfer and equipment concealment, therefore the overall performance level will decline.

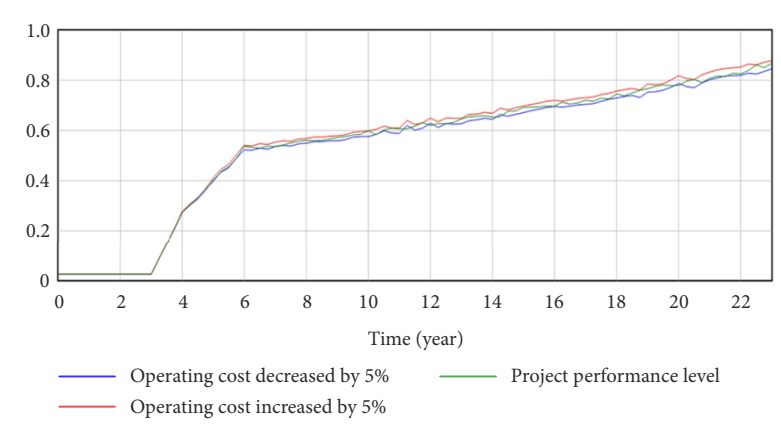

Figure 17. The effect of Operating cost on Project performance level

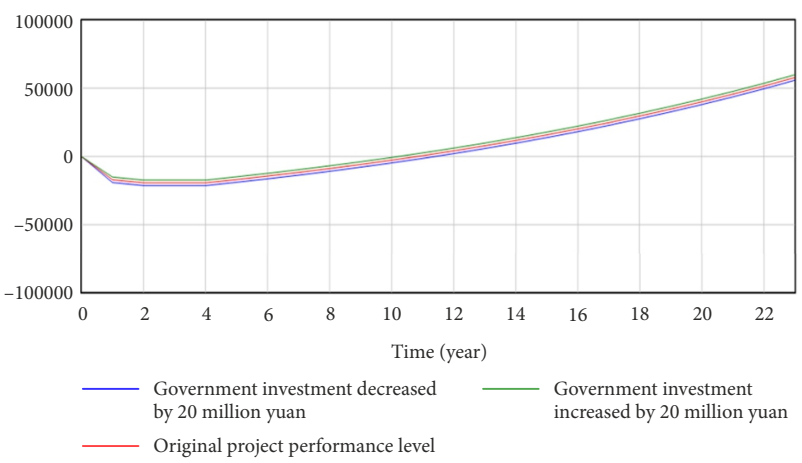

Figure 18. The effect of Government investment on Project performance level

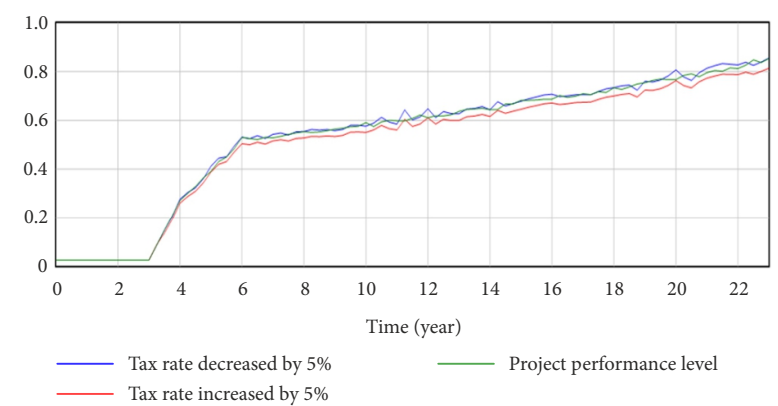

Figure 19. The effect of Tax rate on Project performance level

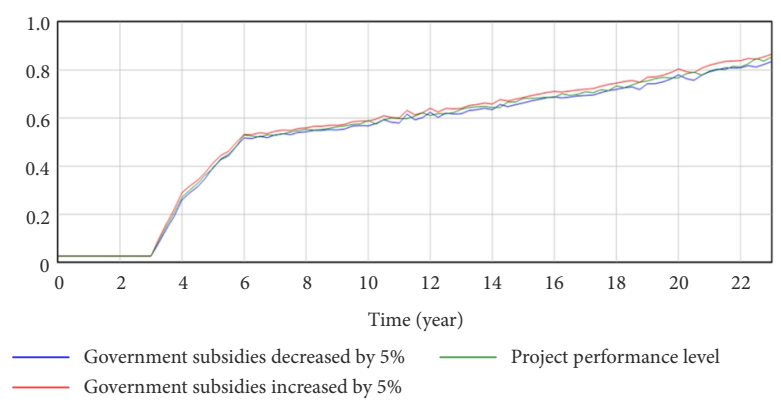

Figure 20. The effect of Government subsidies on Project performance level

(2) Additional hidden area

Figure 24 indicates that when Additional hidden area is increased by $5 \%$, the project performance level will increase. The result indicates that during the project design stage, effective layout to appropriately increasing the hidden area can improve the project performance and give better play to the project combat readiness benefits. 


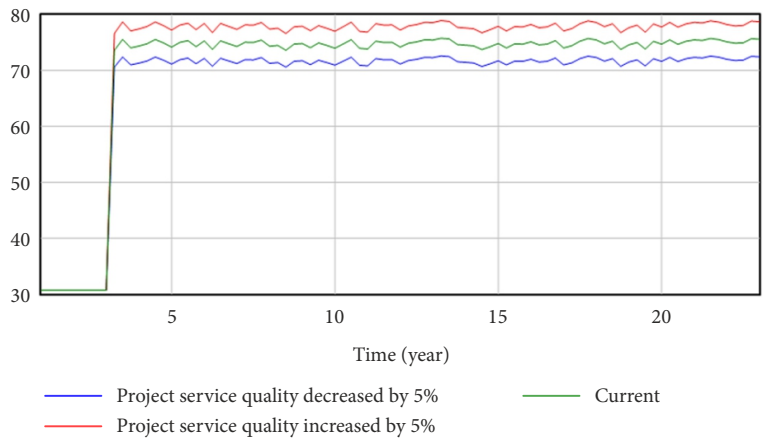

Figure 21. The effect of Project service quality on User satisfaction

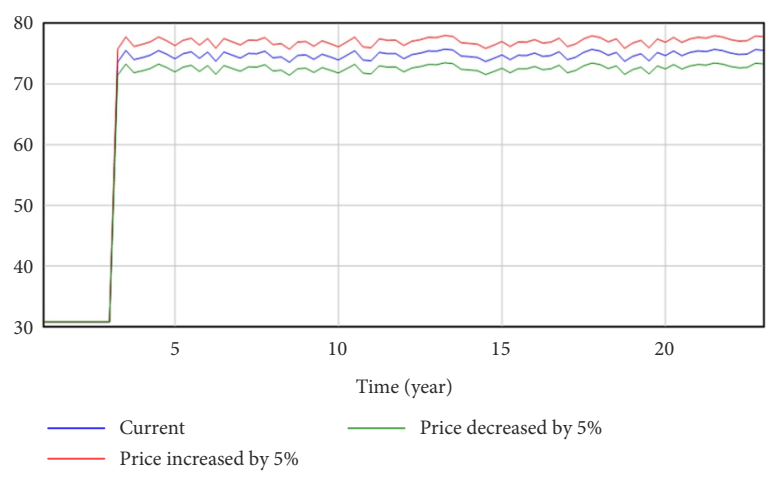

Figure 22. The effect of Price on User satisfaction

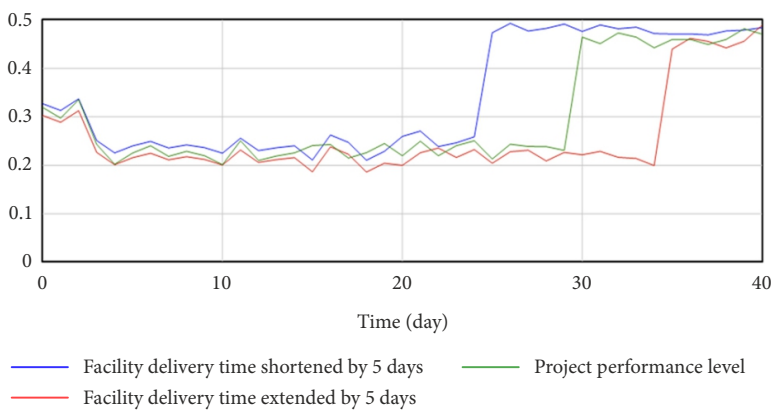

Figure 23. The effect of Facility delivery time on Project performance level

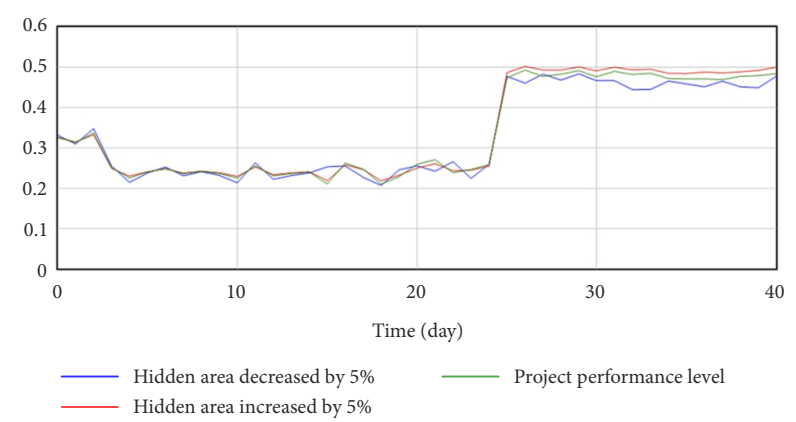

Figure 24. The effect of Additional hidden area on Project performance level

\section{Discussion and implications}

Although the social status of CAD PPP projects has received increasing attention, but their slow return on investment has restricted the construction of the projects.
The main objective of this study is to establish a unified performance measurement model for CAD PPP projects, thereby bridging the gap caused by the scarcity of studies on comprehensive and objective performance measurement for CAD PPP projects on a full lifecycle basis. The case study proved that the proposed SD model can effectively replicate the real system of a CAD PPP project, and the simulation results is consistent with the actual data from the project profile reports.

The presented simulation-based method analysis the project influencing factors from the perspective of private partner, government and the public. The most important factors affecting project performance during peacetime include: Operating costs, Tax rates, User satisfaction and Government subsidies. The private partner concerned most about the project income, from the perspective of project economic benefits, the main affecting factors are the project operating cost and the rationality of project financing structure. The government and private partner should work together to improve the project financing structure, make reasonable project expenditure plans on the premise of ensuring user satisfaction to improve project performance. Because CAD projects are mostly public welfare projects, the fees charged to the public are very limited, so it is difficult for private partners to earn reasonable income through operation. Therefore, government investment directly determines the success of the project, and government investment is related to government subsidies, taxes, etc. As an important participant in CAD PPP projects, government can provide appropriate PPP subsidies and tax deductions according to actual local conditions to reduce the pressure on social capital, and improve the overall project service quality. We can gather that government plays a pivotal role in both construction and operation of CAD PPP projects, and determine a reasonable project return mechanism is one of the key elements for the success of project.

During wartime, the most important factors are Facility delivery time and Additional hidden area. Speeding up the delivery of facilities and increasing the wartime hidden area during the preliminary planning of the project can significantly improve the project performance. Therefore, if $\mathrm{CAD}$ is included in the overall planning of social development and urban construction, the performance of CAD project can be greatly promoted.

The results imply that the improvement of CAD PPP project performance level requires the joint efforts of government and private partner. While government plays an important role in the CAD PPP project, when various factors cannot be considered comprehensively, priority should be given to reduce tax rates and increase government subsidies. Secondly, consideration should be given to improve the financing structure and control project operating costs.

The following are implications for the future development and improvement of project performance at policy level. 
(1) Improve laws and regulations related to CAD projects. Although the Property Law stipulates that national defense assets belong to the state, it has not yet defined whether CAD projects are national defense assets. The unclear property rights will affect the enthusiasm of private partner to invest in CAD projects and thus affect the development of CAD projects in China. The ownership of CAD projects should be clarified, and use rights should be separated from property rights.

(2) Expand investment and financing channels for CAD projects. Although more attention has been paid on CAD projects, but due to their slow return on investment and other characteristics, their construction and development is restricted. Under the conditions permitted by national policies, the government can provide private enterprises with financing services and preferential tax policies.

(3) Transform government functions to service-oriented government. At present, most of the management and operation of CAD projects are undertaken by local government departments. Through introducing social capital to participate, the construction and management of CAD projects can be entrusted to a special company, with government department guarantees certain supervision and control.

(4) Greater importance should be attached to consultation and communication. PPP projects involve many stakeholders, which requires smooth coordination and cooperation between all stakeholders. The government should allow better communication between private partner and relevant government departments.

(5) CAD projects should be included in the overall planning of urban construction. To effectively improve CAD construction, it is necessary to shift from relying on emergency preparedness in the past to coordinated CAD construction with economic construction and urban construction in a planned and focused manner.

\section{Conclusions}

In order to improve the quality of CAD projects, effectively utilize the underground space, and alleviate government's financial pressure, PPP mode is widely applied in the construction of CAD projects. However, the performance measurement of CAD PPP project has failed to keep up with the pace of the project development, there are many shortcomings in both theoretical research and practical applications. In this paper, a three-dimensional indicator variable analysis model based on the expected project performance targets, the main stakeholders and the project evaluation stages is constructed to form the performance measurement indicator system of CAD PPP projects. A SD model is constructed to simulate the dynamic relationships among the performance measurement indicators. A case study is conducted to verify the effectiveness of the proposed SD model. By simulating the performance of CAD PPP project with different parameters, decision makers can analyze the possible causes of differ- ent results, and understand the dynamic process of project performance management from multiple angles and levels. The results show that government should give priority to reduce tax rates and increase government subsidies, which also reflects the important role of the government in CAD PPP projects. The private partner should consider improving the financing structure and controlling project operating costs to ensure user satisfaction. Corresponding improvement strategies are proposed from the perspective of government and private partner to jointly promote the improvement of project performance. The study result can make the performance management more scientific and reasonable, meanwhile helping decision makers to formulate effective performance improvement strategies. In addition, the proposed performance measurement $\mathrm{SD}$ model allows alternations in model variables according to different situations, therefore is universal and reproducible to other CAD PPP projects in other regions.

Despite of the contributions, some disadvantages should be improved in future. Firstly, because there is insufficient literature on CAD projects, this paper refers to some relevant laws and policies on underground space management to ensure the comprehensiveness of the indicator system. Subsequent research can be conducted on more specific CAD projects. Secondly, when defining the system boundary, this paper only considers the perspective of the core stakeholders: the government, private partner and the public. CAD PPP projects involve many other participants such as financial institutions, contractors and suppliers, in the follow-up study, the system boundary can be further expanded.

\section{Acknowledgements}

The authors' special thanks go to all survey participants and reviewers of the paper, and to the National Natural Science Foundation of China (No.51978164), Ministry of education in the humanities and social sciences of China (No.20YJCZH182) for financially supporting this research.

\section{References}

Ansari, R. (2019). Dynamic simulation model for project changemanagement policies: Engineering project case. Journal of Construction Engineering and Management, 145(7), 05019008. https://doi.org/10.1061/(ASCE)CO.1943-7862.0001664

Augustínová, E., \& Daubner, M. (2013). Performance measurement and management of public-private partnership projects. In Proceedings of the International Multidisciplinary Scientific GeoConference SGEM (pp. 239-246).

https://doi.org/10.5593/SGEM2013/BE5.V2/S21.032

Bassioni, H. A., Price, A. D. F., \& Hassan, T. M. (2004). Performance measurement in construction. Journal of Management in Engineering, 20(2), 42-50.

https://doi.org/10.1061/(ASCE)0742-597X(2004)20:2(42)

Chester, C. V., \& Zimmerman, G. P. (1987). Civil defense shelters: A state-of-the-art assessment. Tunnelling and Underground Space Technology, 2(4), 401-428.

https://doi.org/10.1016/0886-7798(87)90101-5 
Hu, W., Dong, J., Hwang, B.-g., Ren, R., Chen, Y., \& Chen, Z. (2020). Using system dynamics to analyze the development of urban freight transportation system based on rail transit: A case study of Beijing. Sustainable Cities and Society, 53, 101923. https://doi.org/10.1016/j.scs.2019.101923

Ji, Y., Liu, G., \& Qi, Y. (2019). Research on identification of influencing factors of prefabrication building cost based on improved Entropy and DEMATEL method. In International Conference on Construction and Real Estate Management 2019 (ICCREM 2019) (pp. 570-576).

https://doi.org/10.1061/9780784482308.065

Jia, R., \& Wu, F. (1998). Modeling of RATE variable fundamental in-tree for system dynamics. Systems Engineering - Theory \& Practice, 6, 3-5.

Lee, S. U., \& Stedinger, J. R. (2009). Uncertainty and sensitivity analysis for models with calibrated parameters. In World Environmental and Water Resources Congress 2009. https://doi.org/10.1061/41036(342)521

Li, X., \& Liu, C. (2017). Research on improvement of PPP infrastructure project performance evaluation system based on balanced scorecard. Infrastructure Management Optimization, 29, 11-16.

Liu, J., Love, P. E. D., Davis, P. R., Smith, J., \& Regan, M. (2015). Conceptual framework for the performance measurement of Public-Private Partnerships. Journal of Infrastructure Systems, 21(1), 04014023.

https://doi.org/10.1061/(ASCE)IS.1943-555X.0000210

Ostř́žek, J. (2011). Value for money drivers in PPP projects impact on the czech VFM methodology. Acta Universitatis Bohemiae Meridionales, 14(1), 89-100.

Pagoni, E. G., \& Georgiadis, P. (2020). System dynamics approaches to public-private partnerships: A literature review. Systems Research and Behavioral Science, 37(2), 277-291. https://doi.org/10.1002/sres.2626

Qi, W., \& Kong, L. (2017). Analysis of PPP project performance influence path based on SEM Model. Journal of Wuhan University (Information \& Management Engineering), 39(2), 202-207.

Rossborough, R. J. (1976). The Office of the United Nations Disaster Relief Co-ordinator. Annales De La Societe Belge De Medecine Tropicale, 56(4-5), 361.

Sun, H., Liang, Y. Z., \& Wang, Y. N. (2019). Grey clustering evaluation for the cooperation efficiency of PPP project: Taking Beijing Metro Line 4 as an example. Mathematical Problems in Engineering, Article ID 8232731. https://doi.org/10.1155/2019/8232731

Sun, H., Shen, K., \& Fan, Z. (2012). Analysis of influencing Factors of PPP project performance based on SEM method. Journal of Tianjing University (Social Sciences), 14(6), 513-519.

Tang, S. (2019). Research on the performance evaluation index system of the contract governance in the PPP mode based on the $4 E$ theory. Guangzhou University.

Tang, L. Y., Shen, Q. P., \& Cheng, E. W. L. (2010). A review of studies on Public-Private Partnership projects in the construction industry. International Journal of Project Management, 28(7), 683-694.

https://doi.org/10.1016/j.ijproman.2009.11.009

Villalba-Romero, F., \& Liyanage, C. (2016). Evaluating success in PPP road projects in Europe: A comparison of performance measurement approaches. Transportation Research Procedia, 14, 372-381. https://doi.org/10.1016/j.trpro.2016.05.089

Walters, J. P., Archer, D. W., Sassenrath, G. F., Hendrickson, J. R., Hanson, J. D., Halloran, J. M., Vadas, P., \& Alarcon, V. J. (2016). Exploring agricultural production systems and their fundamental components with system dynamics modelling. Ecological Modelling, 333, 51-65.

https://doi.org/10.1016/j.ecolmodel.2016.04.015

Xiong, W., Yuan, J. F., Li, Q., \& Skibniewski, M. J. (2015). Performance objective-based dynamic adjustment model to balance the stakeholders satisfaction in PPP projects. Journal of Civil Engineering and Management, 21(5), 539-547.

https://doi.org/10.3846/13923730.2014.895409

$\mathrm{Xu}, \mathrm{S}$. (2014). Research on current legislation for urban underground space in China. In International Conference on Pipelines and Trenchless Technology 2014, Xiamen, China. https://doi.org/10.1061/9780784413821.001

Xu, Y., Sun, C., Skibniewski, M. J., Chan, A. P. C., Yeung, J. F. Y., \& Cheng, H. (2012). System Dynamics (SD)-based concession pricing model for PPP highway projects. International Journal of Project Management, 30(2), 240-251. https://doi.org/10.1016/j.ijproman.2011.06.001

Xue, C., \& Zhou, J. (2019). System dynamics modeling and analysis of PPP project performance from three-party perspective. Science and Technology Management Research, 39(17), 205-213.

Yan, K., Peng, Y., \& Guo, B. (2019). Research on the performance evaluation of PPP projects in sponge city based on PSIR model. Friends of Accounting, 13, 52-58.

Yang, L., Lei, X., \& Liu, Q. (2017). Research on PPP project performance evaluation based on stakeholder theory. Project Management Technology, 15(8), 25-28.

Yildiz, A. E., Dikmen, I., \& Birgonul, M. T. (2020). Using system dynamics for strategic performance management in construction. Journal of Management in Engineering, 36(2), 04019051. https://doi.org/10.1061/(ASCE)ME.1943-5479.0000744

Yu, B., Zhang, J., Wei, S., Cong, G., Zhang, D., \& Chen, T. (2007). The research on information system project performance evaluation based on fuzzy neural network. In 2007 International Conference on Wireless Communications, Networking and Mobile Computing, Shanghai, China. https://doi.org/10.1109/WICOM.2007.1513

Yu, L., \& Tang, S. (2018). Research on the performance evaluation of contract governance under PPP mode based on " $4 \mathrm{E}$ " theory. Construction Economy, 39(12), 37-42.

Yuan, J., Wang, C., Skibniewski, M. J., \& Li, Q. (2012). Developing key performance indicators for Public-Private Partnership projects: Questionnaire survey and analysis. Journal of Management in Engineering, 28(3), 252-264. https://doi.org/10.1061/(asce)me.1943-5479.0000113

Zhao, X. (2009). Research on PPP projects performance evaluation [Master thesis]. Tsinghua University. 